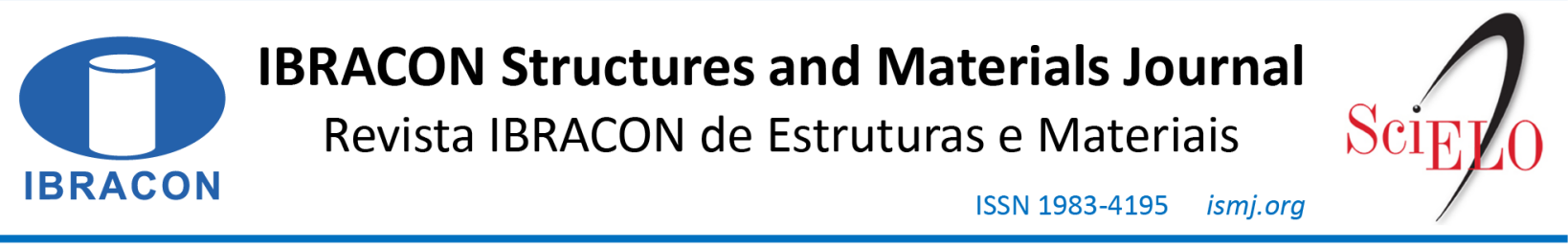

ORIGINAL ARTICLE

\title{
Application of the rebound test for the technological control of concrete hollow-core slabs
}

\author{
Aplicação do ensaio de esclerometria para o controle tecnológico de lajes \\ alveolares de concreto
}

Vladimir Guilherme Haach ${ }^{\mathrm{a}}$ (D)

Mariana Acioli do Carmo Paiva ${ }^{a}$

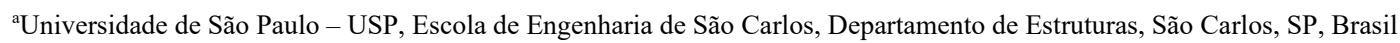

Received 08 November 2018

Accepted 30 January 2020

\begin{abstract}
Hollow-core slabs are precast elements produced with very dry concrete, which hinders the molding of cube or cylindrical specimens normally used for the technological control of the material. This paper addresses the use of the rebound test for the technological control of concrete applied to hollow-core slabs. An experimental program divided into two phases was developed. In the first phase, three concrete mixtures were produced and compressive and rebound tests were performed in cylindrical and prismatic specimens for 6 hours to 28 days for the obtaining of a correlation curve. In the second phase, a hollow-core slab was built with one of the concrete mixtures used and the same tests were applied. The results showed the rebound number correlates well with the compressive strength, which confirms the possible application of the test for the technological control of the concrete used in the construction of hollow-core slabs.
\end{abstract}

Keywords: non-destructive tests, rebound, hollow-core slab, technological control.

Resumo: As lajes alveolares são elementos pré-fabricados produzidos com concreto muito seco, o que dificulta a moldagem de amostras cúbicas ou cilíndricas normalmente utilizadas para o controle tecnológico do material. Este artigo aborda o uso do ensaio de esclerometria para o controle tecnológico do concreto aplicado em lajes alveolares. Um programa experimental dividido em duas fases foi desenvolvido. Na primeira fase, três misturas de concreto foram produzidas e testes de compressão e esclerometria foram realizados em amostras cilíndricas e prismáticas por 6 horas a 28 dias para a obtenção de uma curva de correlação. Na segunda fase, foi construída uma laje alveolar com uma das misturas de concreto utilizadas e os mesmos testes foram aplicados. Os resultados mostraram que o índice esclerométrico se correlaciona bem com a resistência à compressão, o que confirma a possível aplicação do teste para o controle tecnológico do concreto utilizado na construção de lajes alveolares.

Keywords: ensaios não destrutivos, esclerometria, laje alveolar, controle tecnológico.

How to cite: V. G. Haach, and M. A. C. Paiva, "Application of the rebound test for the technological control of concrete hollow-core slabs," Rev. IBRACON Estrut. Mater., vol. 13, no. 4, e13406, 2020, https://doi.org/10.1590/S1983-41952020000400006

\section{INTRODUCTION}

The constant demand for the rationalization of civil construction increases the application of structural systems with a higher level of industrialization. Precast concrete elements have gained space in the construction scenario due to the advantages they offer, as speed, competitiveness, time and cost control, durability and safety. Hollow-core slabs have been distinguished by their versatility in civil construction, since they can be supported by masonry, steel, precast or cast-in-place concrete structures. They have been widely applied as floors and loadbearing walls of residential, commercial and industrial buildings, as well as bridge decks [1]. As a consequence, extensive research has been conducted towards a deeper 
understanding of their behavior regarding different aspects, as subjection to fire and blast loading [2], [3], fiber strengthened [4], [5], and behavior as a composite section with cast-in-place concrete topping [6], [7].

Hollow core slabs are prestressed elements and, although they can be manufactured in fixed molds, the most common production processes are extrusion and sliding molding [8]. The time spent between the cast and the prestress transference is approximately 24 hours, therefore, the technological control of the concrete must be performed at early ages. According to Mehta and Monteiro [9], the early age covers an insignificant amount of time ( 2 days after production) in the total life of the concrete. However, deficiencies in the characteristics of fresh concrete may influence the end product and reduce its service life. The evaluation of the concrete properties over the early ages is a concern not only in the manufacture of hollow core slabs, but also in other civil engineering works, as construction of massive concrete elements [10], [11], application of shotcrete [12], [13], [14], production of other precast concrete elements [15], [16] and construction of concrete pavements [17]-[19].

The manufacture of hollow core slabs by extrusion involves the application of a very dry concrete to the elements at a 0.30 to 0.40 water/cement ratio $(w / c)$ [8]. Such values are close to the required w/c for the hydration of cement and ensure a concrete of high compressive strength and lower porosity. Its low slump hinders the molding of cube or cylindrical specimens normally used for the technological control of the material. BSI [20] indicates non-destructive tests (NDTs) as useful tools for increasing the confidence level of destructive tests. Azenha et al. [21] continuously monitored the evolution of elastic modulus of a prefabricated beam through modal analysis. Haach and Juliani [22] evaluated the possible application of ultrasonic tests for the technological control of concrete of hollow-core slabs in the production phase and concluded UPV tests can be an interesting alternative for use in precast concrete industries.

PCI [23] also points NDTs may supplement, but not replace, cylinder tests for the evaluation of the compressive strength of concrete and recommends the rebound test as the more common method. The rebound method has been one of the oldest NDTs applied to concrete structures to date. Its principle is based on the correlation between surface hardness measured by a rebound number and the compressive strength of the concrete. PCI [23] highlights the most important criterion is the correlation between rebound number and compressive strength. The literature reports several empirical relations developed from experimental data [24]-[29]. Pascale et al. [30] studied nondestructive tests (UPV, rebound hammer, probe penetration, etc.) applied to high-strength concrete representing the regression curves by power functions as Equation 1 , where $f_{c}$ is the estimated cube strength in $\mathrm{MPa}, \mathrm{x}$ is the nondestructive parameter typical of the method used and $\alpha$ and $\beta$ are parameters obtained by the ordinary least-squares method applied to the experimental data.

$$
f_{c}=\alpha x^{\beta}
$$

Mohammed et al. [31] studied the behavior of concrete containing crumb rubber as a replacement of fine aggregate and proposed an exponential relationship between compressive strength and rebound number. Szilágyi et al. [32] proposed a phenomenological constitutive model (SBZ-model) formulated for the surface hardness of concrete based on the time-dependent development of the capillary pore system of the hardened cement paste. The authors demonstrated its applicability for CEM I $42.5 \mathrm{~N}$, CEM II/A-V 42.5 N and CEM III/B $32.5 \mathrm{~N}$ cements in a 0.38 to 0.60 range of water/cement ratio and 7 to 180 days of concrete. Tsioulou et al. [33] evaluated the mechanical characteristics of ultra-high performance fibre-reinforced concrete (UHPFRC) and proposed linear, power and exponential relationships between compressive strength and rebound number. Völgyi and Farkas [34] highlighted the non-destructive testing functions developed for vibrated concrete are not applicable for dry concrete, since the results of rebound tests strongly depend on the properties of the microenvironment of the material. Völgyi and Farkas [34] studied spun-cast concrete elements produced at low water/cement ratios. In general, the limitations of all proposed formulations regarding the influence of variables, as smoothness of test surface, size, shape, and rigidity of the specimens, moisture and type of cement and aggregates, lead to a high coefficient of variation [35].

Since NDT is an easy, quick and inexpensive test, researchers continue proposing improvements and new applications for the rebound test method [30], [36], [37].

This paper discusses the possible advantages and limitations of the use of the rebound hammer for improving the technological control of the concrete used in the manufacture of hollow core slabs.

\section{EXPERIMENTAL PROGRAM}

The experimental program was divided into two phases. The first involved the evaluation of three different concrete mixtures through compressive and rebound tests for the obtaining of the variation in the concrete behavior during the hardening process and correlation curves between compressive strength and rebound number. In the second phase, a 
hollow-core slab was built in the laboratory with one of the concrete mixtures tested in the previous phase for the evaluation of the applicability of the rebound test for the technological control of the concrete in those elements.

\subsection{Properties of materials}

Type III Portland cement of high early strength specified according to the ASTM C150 [38] classification, sand and gravel were used in the preparation of the concrete. Sand has $2.4 \mathrm{~mm}$ maximum size and 1.95 fineness modulus, whereas gravel has $12.7 \mathrm{~mm}$ maximum size and 6.84 fineness modulus. Figure 1 displays the particle size distribution for sand and gravel and Table 1 shows some physical properties of the materials. The standard procedure described in ASTM C192 [39] was applied to the mixtures. Three different compositions of concrete (M1 to M3) were produced, according to Table 2 . The mixtures were defined through a $100 \mathrm{~mm}$ slump and three different binder/aggregate ratios $(1: 3.5 ; 1: 5.0$ and $1: 6.5)$. The dry mortar ratio defined by Equation 2 , shown in Oliveira et al. [40], was set to $51 \%$. Only one batch of concrete was produced for each mixture.

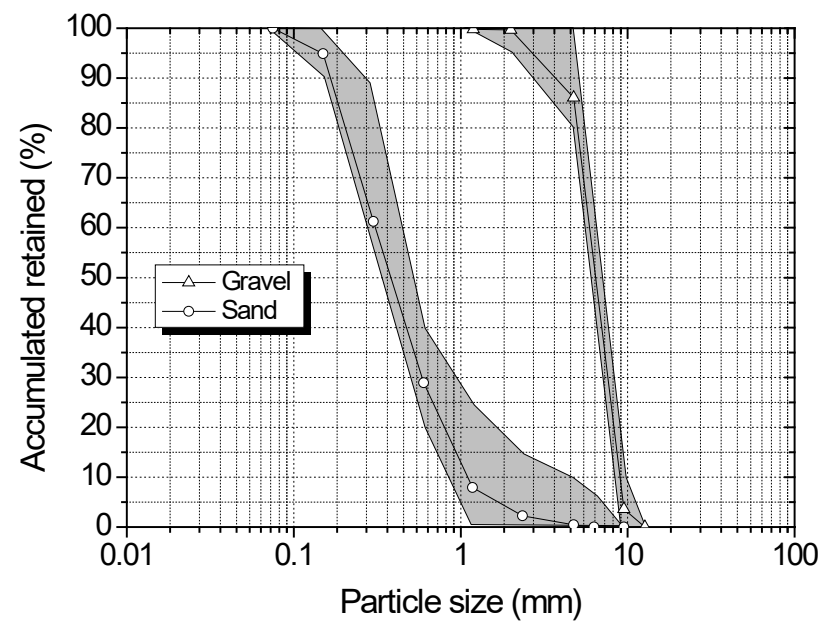

Figure 1 - Grading curve of aggregates.

Table 1 - Properties of materials.

\begin{tabular}{cccc}
\hline & Cement & Sand & Gravel \\
\hline Bulk density $\left(\mathrm{kg} / \mathrm{m}^{3}\right)$ & 1171 & 1565 & 1498 \\
\hline Density $\left(\mathrm{kg} / \mathrm{m}^{3}\right)$ & 3070 & 2625 & 2804 \\
\hline
\end{tabular}

Table 2 - Compositions of concrete $\left(\mathrm{kg} / \mathrm{m}^{3}\right)$.

\begin{tabular}{cccccc}
\hline ID & Cement & Sand & Gravel & Water & $\begin{array}{c}\text { Water/cement } \\
\text { ratio }\end{array}$ \\
\hline M1 & 484.6 & 630.0 & 1066.2 & 227.8 & 0.47 \\
\hline M2 & 378.8 & 780.4 & 1113.8 & 227.3 & 0.60 \\
\hline M3 & 295.0 & 834.6 & 1141.5 & 224.2 & 0.76 \\
\hline
\end{tabular}

$D(\%)=\frac{1+\text { sand }}{1+\text { sand }+ \text { gravel }}$

\subsection{Test specimens}

In the first phase of this research, cylindrical specimens of $100 \mathrm{~mm}$ diameter and $200 \mathrm{~mm}$ height and prismatic specimens of $150 \mathrm{~mm} \times 150 \mathrm{~mm} \times 500 \mathrm{~mm}$ were molded according to ABNT NBR 5738 [41]. The former was removed from the molds after 7 hours, whereas prismatic specimens were kept inside the metallic molds for avoiding any possible 
damage during manipulation due to their weight. Forty-five cylindrical and eight prismatic specimens were molded from each concrete mixture and kept in the laboratory environment during all tests. Compressive and rebound tests were performed at thirteen different ages between 8 hours and 24 hours after the concrete batch and at 7 and 28 days.

In the second phase, hollow-core slabs of $500 \mathrm{~mm} \times 100 \mathrm{~mm}$ cross section dimensions and $2000 \mathrm{~mm}$ length were built with concrete mixture M1, as shown in Figure 2. Four longitudinal bars of $6.3 \mathrm{~mm}$ diameter with $500 \mathrm{MPa}$ nominal yield strength were placed at the top of the slab from the edge to the mid-span on one side for evaluations of their influence on the results regarding presence of reinforcements. A welded mesh composed of $4.2 \mathrm{~mm}$ diameter wires with uniform spacing of $10 \mathrm{~cm}$ was used at the bottom of the slabs to avoid damages during the transport of the model. Thirty cylindrical specimens were also molded with the hollow-core slab for the evaluation of the compressive strength of the concrete at different ages. Hollow cores were generated by PVC tubes positioned in the formwork and removed after the curing of the concrete.

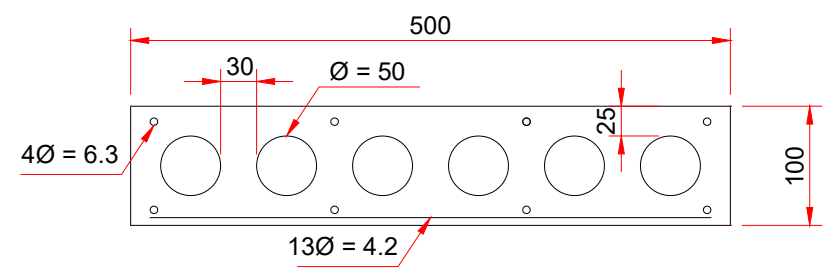

Figure 2 - Geometrical properties of hollow-core slabs. (Note: units in mm).

\subsection{Compressive tests}

Compressive tests were performed in cylindrical specimens according to ASTM C39/C39M [42]. Neoprene pads of 70 durometer hardness were used on top and bottom of the specimens for providing a uniform load distribution during the test, according to ASTM C1231 [43]. Three specimens were tested at each age.

\subsection{Rebound tests}

Rebound tests were applied to the prismatic specimens in the first phase and on the hollow-core slab in the second phase, according to ASTM C805/C805M [44]. Although the standard recommends 10 measurements under the same nominal condition, the rebound number was calculated as the mean of sixteen readings at each age with a $30 \mathrm{~mm}$-spacing between impact points for improving the accuracy of the results. In both phases, the steel plunger of the rebound hammer was positioned in the gravity direction. As the readings were performed with the rebound hammer always in the same position, no correction factors were applied to the rebound number.

In the first phase, 32 impacts were applied on the top face of the prisms ensuring readings of two ages per prismatic specimen. The prisms were kept directly supported on the floor of the laboratory.

In the second phase, ten $150 \mathrm{~mm}$ transversal bands were defined on top of the hollow-core slab for the rebound tests. Five bands were positioned on the half slab with reinforcements (named BR) and five bands were placed on the half slab without reinforcements (named BW). Similarly to the first phase, the readings of two ages per band were performed.

\section{EXPERIMENTAL RESULTS}

The analyses and discussions of the results were also divided into two parts, according to the experimental program. The results of the first phase are showed and discussions on the evolution of the rebound number and compressive strength over time and the correlation curve between those properties were developed. The results of the rebound and compressive tests performed in a hollow core slab are provided and highlight the difficulties and differences in the technological control of the structural member and specimens used in the first phase.

\subsection{Phase I - Evaluation of cylindrical and prismatic specimens}

Compressive strength and rebound number were measured in cylindrical and prismatic specimens, respectively, for three different concrete mixtures. Table 3 shows the mean values and the coefficients of variation (C.V.) of the results. The rebound 
number was null at the first three ages for the three concrete mixtures due to the small hardness of the concrete surface and as expected, it showed a higher dispersion than the compressive strength with C.V.s in the $3.37 \%$ to $14.65 \%$ range against $1.97 \%$ to $17.21 \%$ range for the compressive strength. The mean value of the C.V.s of the rebound number was almost twice the C.V.s of the compressive strength. Such a variation did not seem to be influenced by the specimen age.

Table 3 - Test results of the first phase of the experimental program.

\begin{tabular}{|c|c|c|c|c|c|}
\hline \multirow{2}{*}{ ID } & \multirow{2}{*}{$\begin{array}{c}\text { Age } \\
\text { (hours) }\end{array}$} & \multicolumn{2}{|c|}{$\begin{array}{l}\text { Rebound } \\
\text { Number }\end{array}$} & \multicolumn{2}{|c|}{$\begin{array}{c}\text { Compressive } \\
\text { Strength }\end{array}$} \\
\hline & & Mean & $\begin{array}{l}\text { C.V. } \\
(\%)\end{array}$ & $\begin{array}{l}\text { Mean } \\
\text { (MPa) }\end{array}$ & $\begin{array}{l}\text { C.V. } \\
(\%)\end{array}$ \\
\hline \multirow{15}{*}{ M1 } & 8.5 & - & - & 2.76 & 9.85 \\
\hline & 9.5 & - & - & 4.54 & 6.07 \\
\hline & 11.5 & 15.88 & 10.51 & 8.38 & 3.06 \\
\hline & 12.5 & 19.33 & 8.45 & 11.54 & 3.95 \\
\hline & 13.5 & 19.13 & 8.29 & 12.90 & 1.97 \\
\hline & 14.5 & 19.69 & 10.11 & 14.18 & 5.07 \\
\hline & 15.5 & 20.31 & 7.57 & 15.69 & 5.92 \\
\hline & 16.5 & 20.63 & 7.89 & 17.17 & 1.79 \\
\hline & 17.5 & 22.31 & 6.89 & 18.23 & 5.12 \\
\hline & 18.5 & 21.44 & 8.16 & 18.79 & 4.88 \\
\hline & 21.5 & 21.38 & 8.35 & 21.06 & 3.42 \\
\hline & 22.5 & 22.00 & 5.98 & 21.89 & 2.88 \\
\hline & 23.5 & 22.75 & 8.72 & 23.97 & 11.57 \\
\hline & 168 & 26.88 & 8.69 & 46.39 & 7.35 \\
\hline & 672 & 28.07 & 10.64 & 52.56 & 11.17 \\
\hline \multirow{15}{*}{ M2 } & 9.0 & - & - & 2.92 & 17.21 \\
\hline & 11.0 & - & - & 4.68 & 5.42 \\
\hline & 12.0 & 10.56 & 14.65 & 5.26 & 6.82 \\
\hline & 14.0 & 11.75 & 12.62 & 7.58 & 11.75 \\
\hline & 15.0 & 12.13 & 12.00 & 8.19 & 3.07 \\
\hline & 16.0 & 13.75 & 13.14 & 8.91 & 6.06 \\
\hline & 17.0 & 15.81 & 10.89 & 9.67 & 3.51 \\
\hline & 18.0 & 16.13 & 8.44 & 10.15 & 2.00 \\
\hline & 19.0 & 15.27 & 13.21 & 11.13 & 10.91 \\
\hline & 20.0 & 16.69 & 11.10 & 11.47 & 2.54 \\
\hline & 22.0 & 16.94 & 11.90 & 13.30 & 8.07 \\
\hline & 23.0 & 16.88 & 10.57 & 14.24 & 2.87 \\
\hline & 24.0 & 18.31 & 14.48 & 15.40 & 7.73 \\
\hline & 168 & 25.47 & 10.69 & 26.86 & 7.73 \\
\hline & 672 & 26.38 & 7.31 & 33.33 & 3.46 \\
\hline \multirow{14}{*}{ M3 } & 10.5 & - & - & 1.53 & 5.45 \\
\hline & 11.5 & - & - & 1.79 & 5.01 \\
\hline & 13.5 & - & - & 2.40 & 7.91 \\
\hline & 14.5 & - & - & 2.90 & 6.02 \\
\hline & 15.5 & - & - & 3.32 & 3.03 \\
\hline & 16.5 & 10.13 & 3.37 & 3.61 & 2.40 \\
\hline & 17.5 & 10.19 & 5.34 & 4.07 & 6.42 \\
\hline & 18.5 & 11.69 & 12.77 & 4.33 & 8.21 \\
\hline & 19.5 & 12.31 & 10.15 & 5.30 & 10.42 \\
\hline & 22.5 & 13.44 & 10.51 & 7.43 & 5.59 \\
\hline & 23.5 & 13.00 & 11.92 & 7.70 & 2.68 \\
\hline & 24.5 & 15.06 & 9.22 & 8.93 & 3.52 \\
\hline & 168 & 22.88 & 9.15 & 24.45 & 4.62 \\
\hline & 672 & 28.69 & 10.24 & 31.21 & 3.23 \\
\hline
\end{tabular}

The monitoring of the evolution of compressive strength of the concrete during the production process of precast elements is fundamental for the prestress transference operation and demolding of the elements. Fib Bulletin 55 [45] proposes an exponential equation for the prediction of the compressive strength $\left(f_{c}(t)\right)$ at age $t$ (in days), from the 
strength at 28 days $\left(f_{c}(28)\right)$, see Equation 3 . The equation is valid for ages between 3 and 28 days and $s$ depends on the strength class of cement and hardening characteristics - its value for type III cement is 0.2 .

$$
\boldsymbol{f}_{\boldsymbol{c}}(\mathbf{t})=\boldsymbol{\beta}_{\boldsymbol{c}}(\mathbf{t}) \boldsymbol{f}_{\boldsymbol{c}}(28) \rightarrow \boldsymbol{\beta}_{\boldsymbol{c}}(\mathbf{t})=\exp \left\{s\left[1-(28 / \boldsymbol{t})^{0.5}\right]\right\}
$$

An exponential function (Equation 4) based on fib equation was fit to the results of compressive strength over 672 hours - 28 days (Figure 3). The coefficient of determination $\mathrm{R}^{2}$ was higher than 0.97 for all mixes. $\mathrm{R}^{2}$ for the fib equation applied to concrete mixtures M1, M2 and M3 was $0.67,0.74$ and 0.89 , respectively. The fib equation reasonably predicted the compressive strength of all mixtures at 7 days and 28 days, as shown in Figure 3a. However, it overestimated the compressive strength in the first 24 hours (Figure 3b).

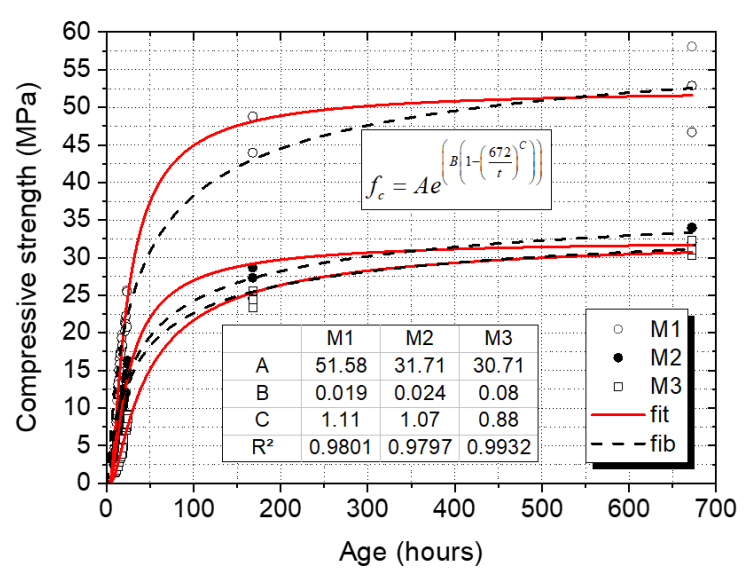

(a)

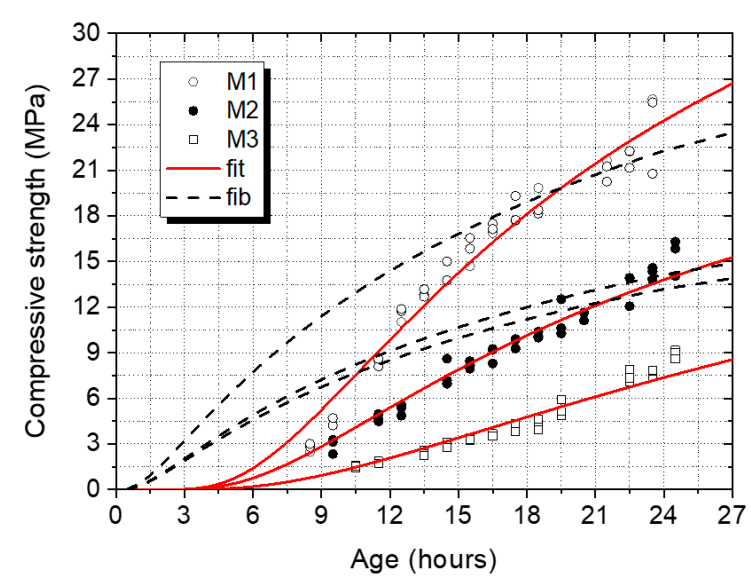

(b)

Figure 3 - Variation in the compressive strength over time: (a) during 28 days and (b) during 24 hours

$$
\boldsymbol{y}(\mathbf{t})=\boldsymbol{A} \xi(\mathbf{t}) \rightarrow \xi(\mathbf{t})=\exp \left\{\boldsymbol{B}\left[1-(28 / \boldsymbol{t})^{C}\right]\right\}
$$

where $y(t)$ is the compressive strength or rebound number and $A, B$ and $C$ are coefficients obtained by the ordinary least-squares method applied to the experimental data.

All compressive strength data in Figure 4 were normalized by the value at 28 days, since the fib proposition considers only the effect of cement type on the variation of compressive strength over age, (Equation 3 ), and all concrete mixtures were produced with the same cement type. A high dispersion is observed in the first 24 hours and indicates the material proportions significantly influence the variation in the compressive strength at early ages.

As the proposition here is to apply rebound tests to supplement the technological control of concrete used in hollow-core slabs, the evolution of rebound number over time was also analyzed. Rebound and compressive tests showed a similar behavior (Figure 5 and Figure 6). The exponential curve represented by Equation 4 seems to express the variations in both properties and the proportions of the materials clearly influenced the variation in the rebound number at early ages. Coefficients A, B and C in Equation 4 can express this dependence on the concrete composition. The cement type probably contributes to variations in such coefficients, as pointed out in the expressions presented in fib Bulletin 55 (2010). Variations in coefficients B and C strongly influenced the curve behavior in the first hours. Both parameters B and C define the strength gain of the material (Figure 7).

Compressive strength, $f_{c}$, and rebound number, $R N$, highly correlated with coefficients of determination $\mathrm{R}^{2}$ higher than 0.95 for all concrete mixtures. A power expression, as Equation 1 used by Pascale et al. [30], was the curve, which best represented the relation between both properties (Figure 8), see Equation 5. 


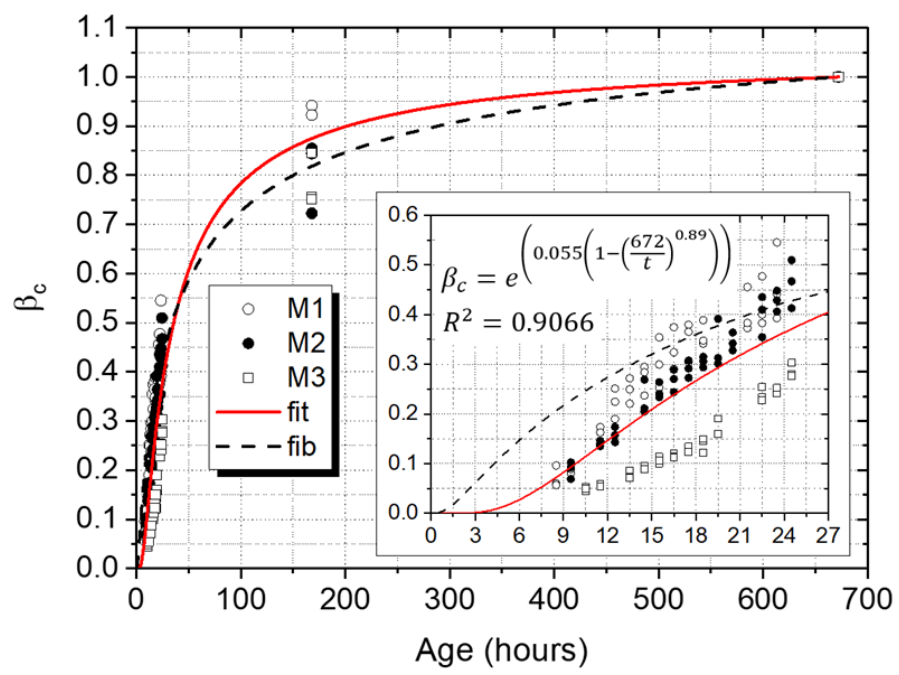

Figure 4 - Variation in the normalized compressive strength over age.

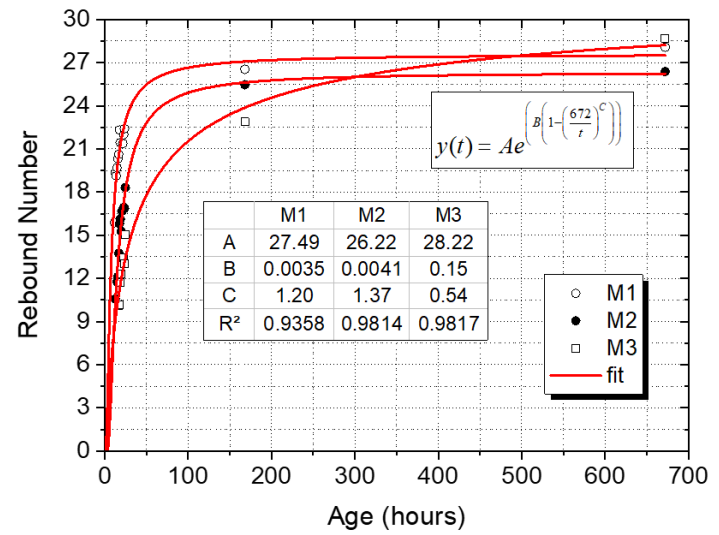

(a)

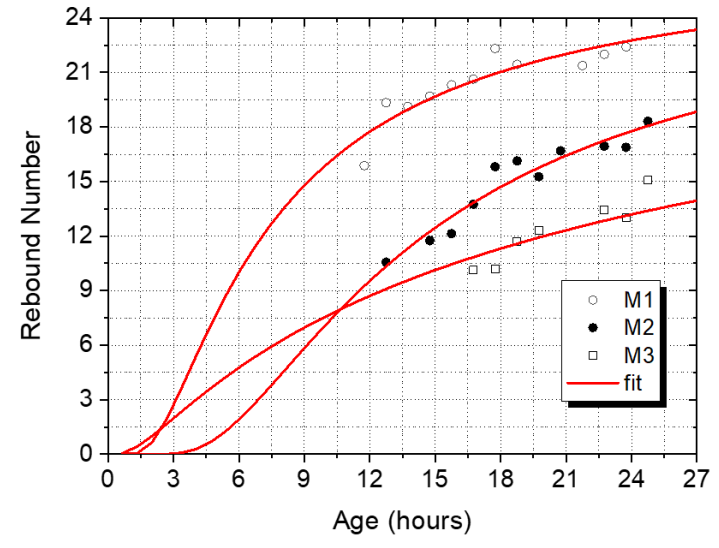

(b)

Figure 5 - Variation in the rebound number over age: (a) over 28 days and (b) over 24 hours.

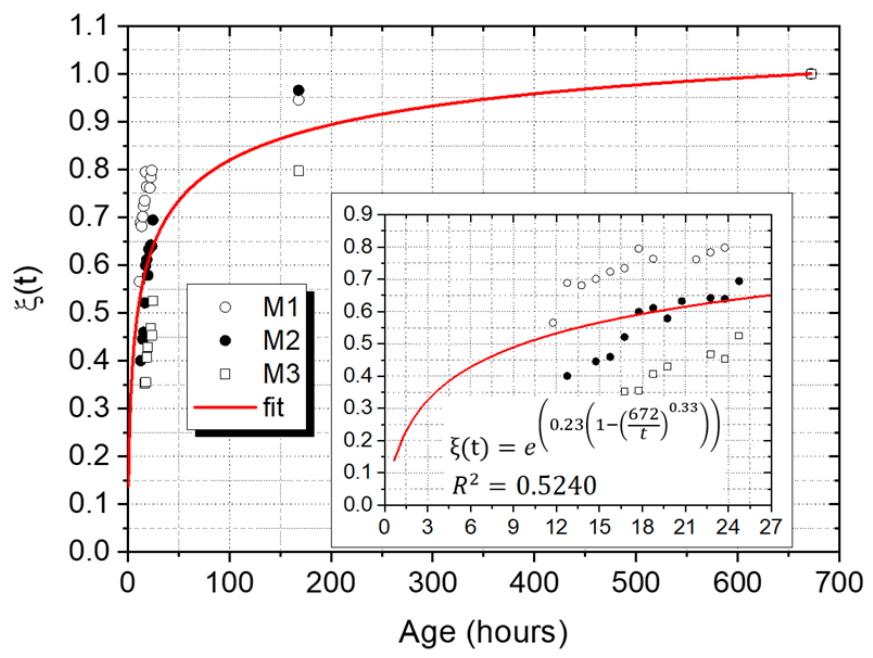

Figure 6 - Variation in the normalized rebound number over age. 


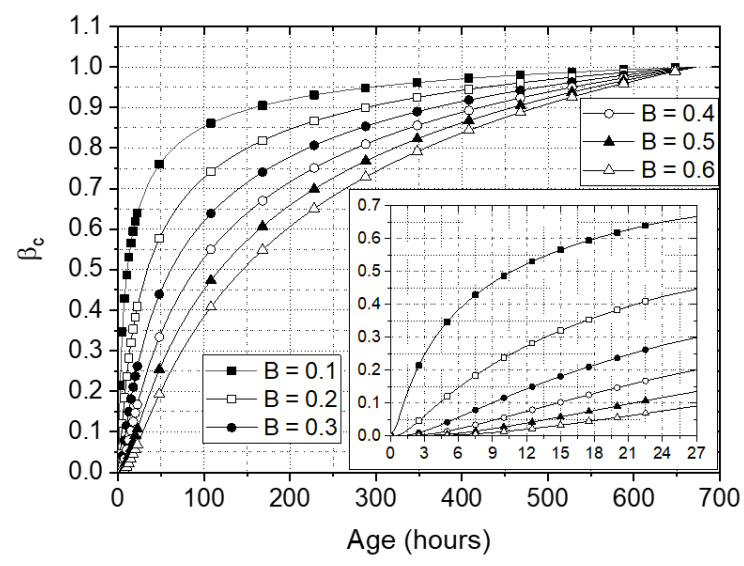

(a)

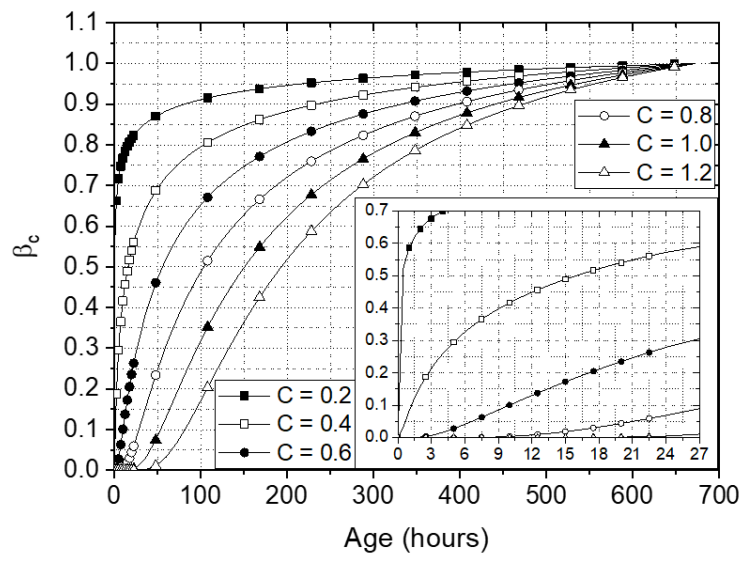

(b)

Figure 7 - Variation in coefficient $\beta_{c}$ with the constants: (a) $\mathrm{B}$ variable and $\mathrm{C}=0.5$ and (b) $\mathrm{C}$ variable and $\mathrm{B}=0.2$.

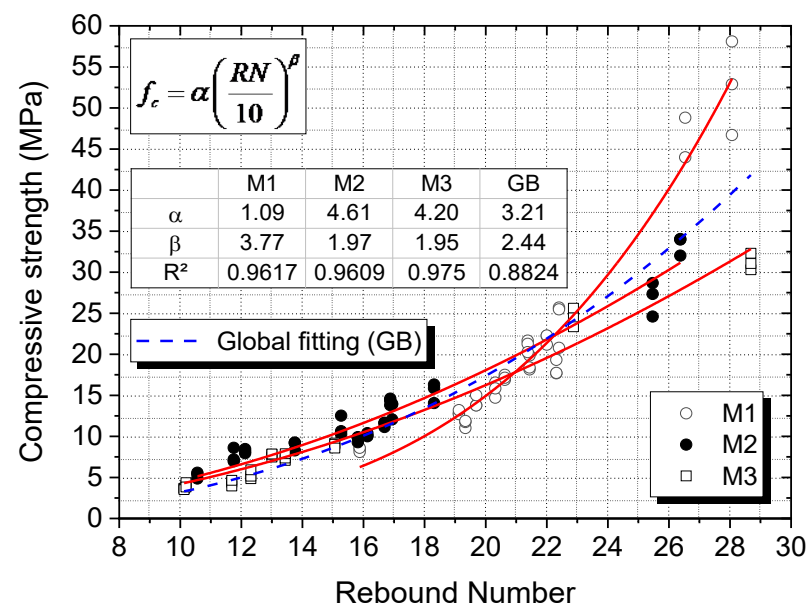

Figure 8 - Correlation between compressive strength and rebound number in phase I.

$f_{c}=\alpha\left(\frac{R N}{10}\right)^{\beta}$

Figure 9 shows the comparison of the phase I results with some correlation curves reported in the literature. The region formed by correlations encompasses all experimental results, which corroborates previous research. However, a high variability is observed in those relations between compressive strength and rebound number, due to the several variables cited in the introduction. This variation seems to increase for the highest values of compressive strength.

\subsection{Phase II - Evaluation of a hollow-core slab}

A hollow-core slab was produced with mix 1 in the laboratory. Rebound tests were performed and the results were compared with those of the first phase. Table 4 shows the results of the rebound tests and the compressive strength obtained from cylindrical specimens molded with the same concrete used in the hollow-core slab.

One of the issues evaluated was the effect of cores on the results of rebound tests. The measurements taken in hollow-core slabs were uniformly distributed over the top of the slab. Measurement points were located above the cores and over the webs, see Figure 10. The results showed the rebound number was not affected by the presence of holes in the cross-section. 


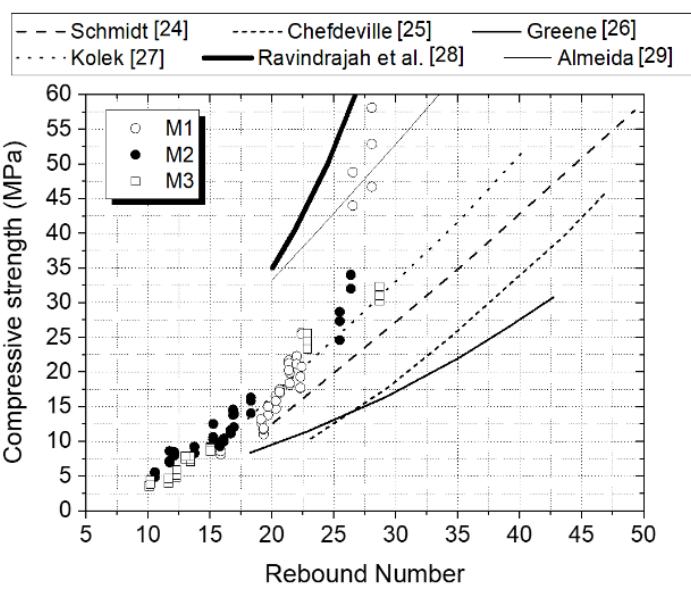

Figure 9 - Comparison between experimental data and correlation curves reported in the literature.

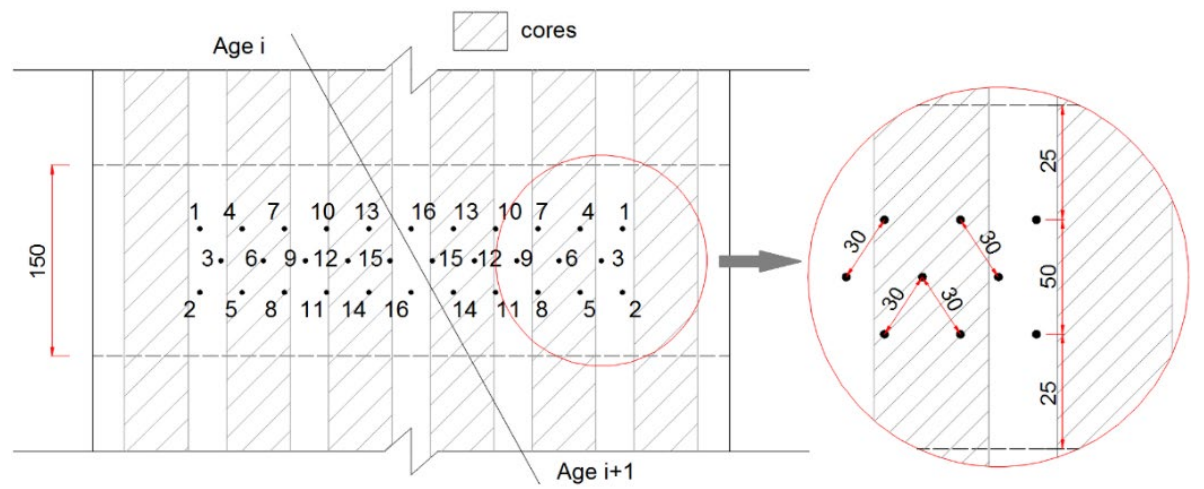

Figure 10 - Location of the measurements in the hollow-core bands (Note: units in $\mathrm{mm}$ ).

Table 4 - Test results of the second phase of the experimental program.

\begin{tabular}{|c|c|c|c|c|c|c|c|}
\hline \multirow{2}{*}{ ID } & \multirow{2}{*}{$\begin{array}{c}\text { Age } \\
\text { (hours) }\end{array}$} & \multicolumn{2}{|c|}{$\begin{array}{l}\text { Rebound } \\
\text { Number }{ }^{1}\end{array}$} & \multicolumn{2}{|c|}{$\begin{array}{l}\text { Rebound } \\
\text { Number }\end{array}$} & \multicolumn{2}{|c|}{$\begin{array}{l}\text { Compressive } \\
\text { strength }\end{array}$} \\
\hline & & Mean & $\begin{array}{l}\text { C.V. } \\
(\%)\end{array}$ & Mean & $\begin{array}{l}\text { C.V. } \\
(\%)\end{array}$ & $\begin{array}{l}\text { Mean } \\
\text { (MPa) }\end{array}$ & $\begin{array}{l}\text { C.V. } \\
(\%)\end{array}$ \\
\hline \multirow{10}{*}{ M1 } & 9.17 & 23.19 & 8.37 & 23.80 & 11.14 & 11.14 & 3.50 \\
\hline & 10.88 & 23.63 & 9.26 & 27.06 & 12.03 & 18.02 & 5.25 \\
\hline & 13.90 & 25.92 & 6.95 & 26.77 & 9.90 & 21.64 & 6.26 \\
\hline & 15.88 & 25.93 & 7.50 & 24.88 & 12.62 & 23.58 & 2.74 \\
\hline & 17.83 & 27.67 & 9.33 & 27.33 & 10.41 & 24.21 & 3.94 \\
\hline & 19.93 & 26.13 & 9.36 & 26.27 & 7.94 & 26.05 & 3.60 \\
\hline & 22.87 & 27.31 & 8.53 & 27.67 & 9.82 & 27.90 & 3.61 \\
\hline & 24.97 & 27.06 & 8.58 & 26.88 & 11.44 & 30.14 & 3.04 \\
\hline & 168 & 28.06 & 12.31 & 27.93 & 10.65 & 42.88 & 6.46 \\
\hline & 672 & 31.43 & 7.14 & 32.07 & 6.52 & 50.82 & 4.58 \\
\hline
\end{tabular}

1 - Rebound Number in the region of the slab with no superior reinforcements. ${ }^{2}-$ Rebound Number in the region of the slab with superior reinforcements.

Figure 11 displays the variation in the rebound number along the width of the hollow-core slab. No pattern related to the position of the cores and webs in regions with (BR) or without (BW) superior reinforcements was observed. Two statistical hypothesis tests, namely F-test and T-test, were applied to the rebound measurements towards improving the evaluation. F-test compares two samples for testing the hypothesis of equality of their variances, whereas T-test determines if they are significantly different. A 5\% significance level was assumed in both tests. 


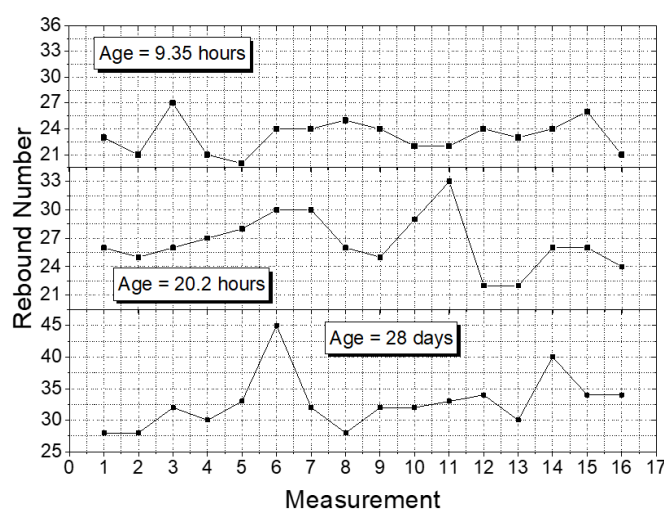

(a)

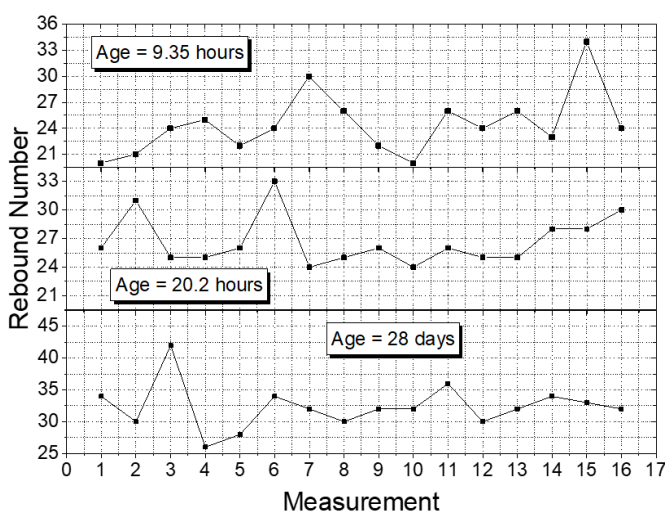

(b)

Figure 11 - Variation in the rebound number along the width of the hollow-core slab in the regions: (a) BW and (b) BR.

Rebound measurements were divided into two groups according to their position (Table 5), i.e., above the webs (1, 2, 3, 9 , 10 and 16) and over the cores $(4,5,6,7,8,12,13,14$ and 15). Readings different from the average by more than 6 units were discarded, as recommended by ASTM C805/C805M [44]. This procedure was applied to each group separately. F-test was applied to the rebound numbers followed by T-test (Table 6). The former showed the variances in the two groups were equal, whereas T-test indicated the measurements above the webs or cores were not significantly different in most cases. The results were obtained in both regions of the hollow-core slab with and without reinforcements, however, in the former, three ages exhibited probabilities for T-test lower than 5\%.

Table 5 - Rebound measurements of the second phase of the experimental program divided by groups.

\begin{tabular}{|c|c|c|c|c|c|c|c|c|}
\hline \multirow{2}{*}{$\begin{array}{c}\text { Age } \\
\text { (hours) }\end{array}$} & \multicolumn{2}{|c|}{ Web $^{1}$} & \multicolumn{2}{|c|}{ Core $^{1}$} & \multicolumn{2}{|c|}{ Web $^{2}$} & \multicolumn{2}{|c|}{ Core $^{2}$} \\
\hline & Mean & $\begin{array}{l}\text { C.V. } \\
(\%)\end{array}$ & Mean & $\begin{array}{l}\text { C.V. } \\
(\%)\end{array}$ & Mean & $\begin{array}{l}\text { C.V. } \\
(\%)\end{array}$ & Mean & $\begin{array}{l}\text { C.V. } \\
\text { (\%) }\end{array}$ \\
\hline 9.17 & 22.86 & 9.26 & 23.44 & 8.01 & 22.43 & 10.25 & 25.00 & 9.80 \\
\hline 10.88 & 22.86 & 8.90 & 24.22 & 9.18 & 28.57 & 10.07 & 25.13 & 9.38 \\
\hline 13.90 & 23.50 & 15.86 & 26.00 & 7.45 & 29.25 & 7.58 & 25.67 & 8.03 \\
\hline 15.88 & 26.50 & 8.52 & 25.56 & 6.81 & 25.57 & 10.31 & 24.33 & 14.53 \\
\hline 17.83 & 27.83 & 8.63 & 27.56 & 10.28 & 25.86 & 13.10 & 27.67 & 11.57 \\
\hline 19.93 & 25.83 & 6.67 & 26.33 & 11.07 & 26.86 & 9.72 & 25.75 & 5.78 \\
\hline 22.87 & 26.57 & 10.39 & 27.89 & 6.81 & 26.33 & 4.60 & 27.88 & 9.08 \\
\hline 24.97 & 26.86 & 8.97 & 27.22 & 8.77 & 27.00 & 6.05 & 26.78 & 14.79 \\
\hline 168 & 26.14 & 10.46 & 29.56 & 11.24 & 25.40 & 6.59 & 29.33 & 8.86 \\
\hline 672 & 31.29 & 7.54 & 32.63 & 11.22 & 32.67 & 6.32 & 31.00 & 8.83 \\
\hline
\end{tabular}

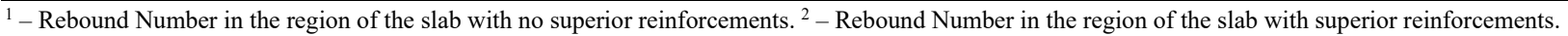

Table 6 - Probabilities of F-Test and T-Test.

\begin{tabular}{|c|c|c|c|c|c|c|}
\hline \multirow{2}{*}{$\begin{array}{c}\begin{array}{c}\text { Age } \\
\text { (hours) }\end{array} \\
\end{array}$} & \multicolumn{2}{|c|}{ Web x Cores ${ }^{1}$} & \multicolumn{2}{|c|}{ Web $x$ Cores ${ }^{2}$} & \multicolumn{2}{|c|}{ With $x$ Without reinforcements } \\
\hline & F-Test & T-Test & F-Test & T-Test & F-Test & T-Test \\
\hline 9.17 & 0.7345 & 0.5662 & 0.8933 & 0.0572 & 0.2421 & 0.4667 \\
\hline 10.88 & 0.8529 & 0.2273 & 0.6095 & 0.0242 & 0.1347 & 0.0015 \\
\hline 13.90 & 0.0987 & 0.1102 & 0.7683 & 0.0163 & 0.1951 & 0.3506 \\
\hline 15.88 & 0.4876 & 0.3762 & 0.4906 & 0.4528 & 0.0812 & 0.2721 \\
\hline 17.83 & 0.7446 & 0.8469 & 0.8571 & 0.2925 & 0.7214 & 0.7394 \\
\hline 19.93 & 0.2614 & 0.7131 & 0.1675 & 0.3230 & 0.5599 & 0.8735 \\
\hline 22.87 & 0.3240 & 0.2765 & 0.1236 & 0.1962 & 0.5616 & 0.6991 \\
\hline 24.97 & 0.9503 & 0.7669 & 0.0444 & 0.8816 & 0.2889 & 0.8470 \\
\hline 168 & 0.6540 & 0.0454 & 0.4123 & 0.0106 & 0.5938 & 0.9109 \\
\hline 672 & 0.3044 & 0.4232 & 0.5539 & 0.2283 & 0.8057 & 0.4401 \\
\hline
\end{tabular}

${ }^{1}$ - Rebound Number in the region of the slab with no superior reinforcements. ${ }^{2}-$ Rebound Number in the region of the slab with superior reinforcements. 
The reinforcement in the superior region of the slabs exerted a very small influence on the rebound tests. The coefficients of variation of the rebound numbers in that region were slightly higher than those of the region without reinforcements. However, F-Test and T-test also indicated the rebound numbers in both regions were not significantly different.

The correlation between the rebound numbers and the compressive strength of the concrete was also little influenced by reinforcements. Fitting equations for both regions with and without reinforcements showed differences lower than $10 \%$ for previsions of the compressive strength from rebound numbers between 26 and 34 (Figure 12 and Figure 13). Compressive strength previsions from rebound number by the equation obtained in phase I for M1 were higher than the compressive strength measured in cylindrical specimens, see. On average, the experimental values of compressive strength were $63 \%$ lower than those predicted.

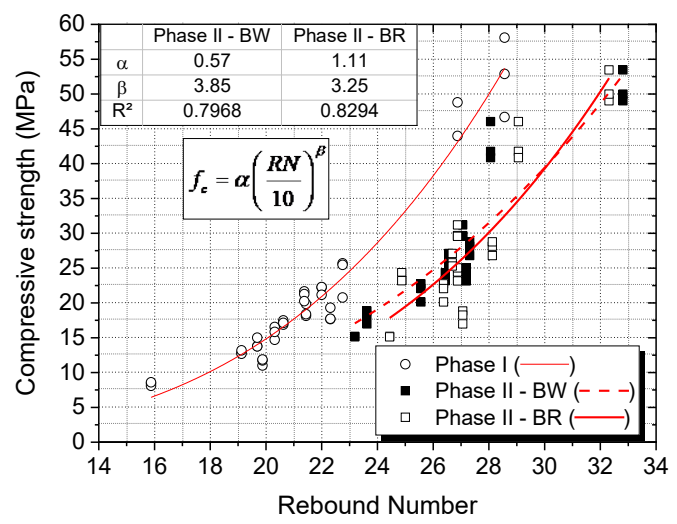

Figure 12 - Correlation between compressive strength and rebound number in phase II.

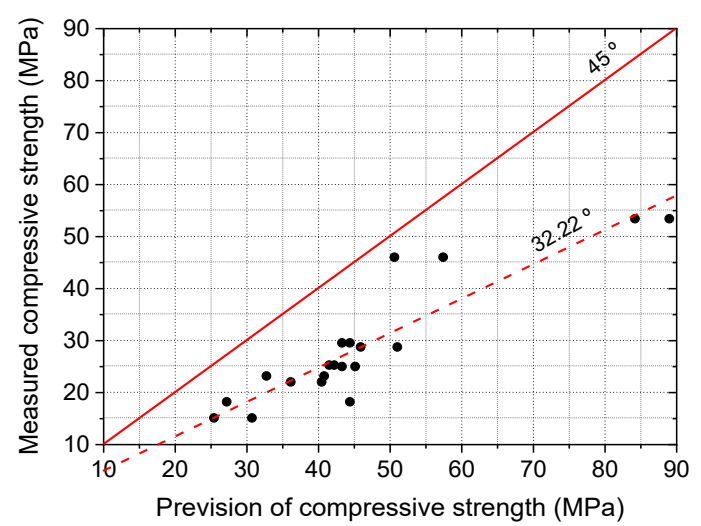

Figure 13 - Relation between prevision and measurement of compressive strength of the concrete used in hollow-core slabs.

In both phases, the compressive strength was evaluated through tests in cylindrical specimens. Differences between measurements and previsions are probably related to the influence of shape and mass of the specimens on the rebound test. In the first phase of the research, prismatic specimens were used in the rebound tests and the rebound numbers ranged from 15.88 to 28.07. In phase II, hollow-core slabs were tested and the rebound numbers were higher than those obtained in phase I, i. e., they ranged from 23.19 to 32.07 . For the same concrete mixture, the hollow-core slab showed rebound numbers more than 15\% higher than those of prismatic specimens. According to Malhotra and Carino [35], if a test specimen is small, any movement under the impact will decrease the rebound number. Prismatic specimens were tested inside the molds at early ages, which probably generates some movement under the impact and caused the behavior pointed out by Malhotra and Carino [35].

Despite the differences in the results of phases I and II, coefficient $\beta$ of the correlation Equation 5 showed a very small variation in all cases and assumed an average value of 3.57. On the other hand, coefficient $\alpha$ showed the highest variation and was influenced by reinforcements, shape and mass of the specimens. 


\section{CONCLUSIONS AND FINAL REMARKS}

This paper has addressed a possible application of rebound tests to improve the technological control of the concrete used in precast hollow-core slabs. The study was divided into two phases for the obtaining of a correlation curve between the rebound number and compressive strength in the first phase to be applied in the second phase, in which a hollow-core slab was produced in the laboratory.

Results of the first phase corroborated with previous research and showed a good correlation between the rebound number and compressive strength of the concrete. However, such a correlation was highly influenced by the concrete mixture. An evolution in the compressive strength and surface hardness gain was observed in this phase. Both properties followed an exponential curve also influenced by the concrete mixture.

Statistical analyses applied to results of tests performed in hollow-core slabs showed both reinforcements and the holes in the cross section exerted a negligible influence on the results of the rebound tests. On the other hand, the correlation curve obtained in phase I did not provide reliable previsions for the compressive strength. The differences in the shape and mass of the specimens used in phases I and II seemed to significantly influence the results.

A very good correlation between rebound number and compressive strength confirmed the possible application of the rebound test for the technological control of the concrete used in the construction of hollow-core slabs. However, the correlation curve to be used for previewing the compressive strength from the rebound number should not be obtained from small specimens, since their shape and mass strongly influence this relation.

\section{ACKNOWLEDGMENTS}

The authors gratefully acknowledge the Laboratory of Structures at the São Carlos Engineering School, where the experimental work was performed, and CAPES (Brazilian government agency for research) for the scholarship provided to the second author. The first author was supported by CNPq (Brazilian government agency for research $\left.\mathrm{N}^{\mathrm{o}} 305441 / 2014-0\right)$.

\section{REFERENCES}

[1] Prestressed Concrete Institute, PCI Design Handbook: Precast and Prestressed Concrete, 6th ed. Chicago: PCI, 2004.

[2] J. V. Aguado, A. Espinos, A. Hospitaler, J. Ortega, and M. L. Romero, "Influence of reinforcement arrangement in flexural fire behavior of hollow core slabs," Fire Saf. J., vol. 53, pp. 72-84, 2012.

[3] A. Maazoun, J. Vantomme, and S. Matthys, "Damage assessment of hollow core reinforced and prestressed concrete slabs subjected to blast loading," Procedia Eng., vol. 199, pp. 2476-2481, 2017.

[4] P. Kankeri and S. S. Prakash, "Experimental evaluation of bonded overlay and NSM GFRP bar strengthening on flexural behavior of precast prestressed hollow core slabs," Eng. Struct., vol. 120, pp. 49-57, 2016.

[5] S. Foubert, K. Mahmoud, and E. El-Salakawy, "Behavior of prestressed hollow-core slabs strengthened in flexure with near-surface mounted carbon fiber-reinforced polymer reinforcement," J. Compos. Constr., vol. 20, no. 6, pp. 10p, 2016.

[6] E. Baran, "Effects of cast-in-place concrete topping on flexural response of precast concrete hollow-core slabs," Eng. Struct., vol. 98, pp. 109-117, 2015.

[7] I. S. Ibrahim, K. S. Elliott, R. Abdullah, A. B. H. Kueh, and N. N. Sarbini, "Experimental study on the shear behaviour of precast concrete hollow core slabs with concrete topping," Eng. Struct., vol. 125, pp. 80-90, 2016.

[8] Prestressed Concrete Institute, PCI Manual for the Design of Hollow Core Slabs, 2nd ed. Chicago: PCI, 1998.

[9] P. K. Mehta and P. J. M. Monteiro, Concrete: Microstructure, Properties and Materials, 3rd ed. New York: McGraw-Hill, 2006.

[10] A. M. Lawrence, M. Tia, C. C. Ferraro, and M. Bergin, "Effect of early age strength on cracking in mass concrete containing different supplementary cementitious materials: experimental and finite-element investigation," J. Mater. Civ. Eng., vol. 24, no. 4, pp. 362-372, 2012.

[11] P. R. Singh and D. C. Rai, "Effect of piped water cooling on thermal stress in mass concrete at early ages," J. Eng. Mech., vol. 144, no. 3 , pp. $04017183,2018$.

[12] J. Sercombe, C. Hellmich, F. J. Ulm, and H. Mang, "Modeling of early-age creep of shotcrete. I: model and model parameters," J. Eng. Mech., vol. 126, no. 3, pp. 284-291, 2000.

[13] C. Hellmich, J. Sercombe, F. J. Ulm, and H. Mang, "Modeling of early-age creep of shotcrete. II: application to tunneling," J. Eng. Mech., vol. 126, no. 3, pp. 292-299, 2000.

[14] A. Mohajerani et al., "Two possible new techniques for determining the early-age shear strength of shotcrete: auger penetrometer and vane shear tester," J. Mater. Civ. Eng., vol. 30, no. 3, pp. 04017298, 2018. 
[15] C. Li, G. Wei, F. Zhang, J. Liu, J. Ma, and T. Ge "Experimental study on high-early-strength precast concrete," in Proc. 10th Asia Pac. Transp. Dev. Conf., Beijing, China, 2014.

[16] Y. H. Kim, M. B. D. Hueste, and D. Trejo, "Flexural behavior of high-early-strength self-consolidating concrete pretensioned bridge girders: experimental evaluation," J. Bridge Eng., vol. 20, no. 2, pp. 04014064, 2015.

[17] J. H. Jeong, D. G. Zollinger, J. S. Lim, and J. Y. Park, "Age and moisture effects on thermal expansion of concrete pavement slabs," J. Mater. Civ. Eng., vol. 24, no. 1, pp. 8-15, 2012.

[18] J. Zhang, D. Hou, and Y. Gao, "calculation of shrinkage stress in early-age concrete pavements. I: calculation of shrinkage strain," $J$. Transp. Eng., vol. 139, no. 10, pp. 961-970, 2013.

[19] J. Zhang, D. Hou, and Y. Gao, "Calculation of shrinkage stress in early-age concrete pavements. II: calculation of shrinkage stress," J. Transp. Eng., vol. 139, no. 10, pp. 971-980, 2013.

[20] British Standards Institution, Guide to the Use of Nondestructive Methods of Test for Hardened Concrete, BS 1881:Part201. London: BSI, 1986.

[21] M. Azenha, L. F. Ramos, R. Aguilar, and J. L. Granja, "Continuous monitoring of concrete E-modulus since casting based on modal identification: a case study," Cement Concr. Compos., vol. 10, pp. 10-15, 2012.

[22] V. G. Haach and L. M. Juliani, "Possibilities of using ultrasound for the technological control of concrete of hollow-core slabs," Constr. Build. Mater., vol. 133, pp. 409-415, 2017.

[23] Prestressed Concrete Institute, PCI Manual for Quality Control for Plants and Production of Structural Precast Concrete Products, 4th ed. Chicago: PCI, 1999.

[24] E. Schmidt, "Rebound hammer for concrete testing," Schweiz Bauztg, vol. 68, no. 28, pp. 378-379, 1950.

[25] J. Chefdeville, Application of the Method Toward Estimating the Quality of Concrete (RILEM Bulletin 15, Special issue-vibration testing of concrete: part 2). Paris: RILEM, 1953.

[26] G. W. Greene, "Test hammer provides new method of evaluating hardened concrete," J. Am. Concr. Inst., vol. 26, no. 3, pp. 249-256, 1954.

[27] J. Kolek, "An appreciation of the Schmidt rebound hammer," Mag. Concr. Res., vol. 10, no. 28, pp. 27-36, 1958.

[28] R. S. Ravindrajah, Y. H. Loo, and C. T. Tam, "Strength evaluation of recycled-aggregate concrete by in-situ tests," Mater. Struct., vol. 21, pp. 289-295, 1988.

[29] I. R. Almeida "Emprego do esclerômetro e do ultra-som para efeito da avaliação qualitativa dos concretos de alto desempenho," Ph.D. dissertation, Univ. Fed. Fluminese, Niteroi, Brasil, 1993.

[30] G. Pascale, A. Di Leo, and V. Bonora, "Nondestructive Assessment of the Actual Compressive Strength of High-Strength Concrete," J. Mater. Civ. Eng., vol. 15, no. 5, pp. 452-459, 2003.

[31] B. S. Mohammed, N. J. Azmi, and M. Abdullahi, "Evaluation of rubbercrete based on ultrasonic pulse velocity and rebound hammer tests," Constr. Build. Mater., vol. 25, no. 3, pp. 1388-1397, 2011.

[32] K. Szilágyi, A. Borosnyói, and I. Zsigovics, "Rebound surface hardness of concrete: Introduction of an empirical constitutive model," Constr. Build. Mater., vol. 25, pp. 2480-2487, 2011.

[33] O. Tsioulou, A. Lampropoulos, and S. Paschalis, "Combined non-destructive testing (NDT) method for the evaluation of the mechanical characteristics of ultra-high performance fibre reinforced concrete (UHPFRC)," Constr. Build. Mater., vol. 131, pp. 66$77,2017$.

[34] I. Völgyi and G. Farkas, "Rebound testing of cylindrical spun-cast concrete elements," Period. Polytechnica, vol. 55, no. 2, pp. 129135, 2011.

[35] V. M. Malhotra and N. J. Carino, Handbook on Nondestructive Testing of Concrete, 2nd ed. Boca Raton: CRC Press, 2004.

[36] M. Saleem, W. A. Al-Kutti, N. M. Al-Akhras, and H. Haider, "Nondestructive testing procedure to evaluate the load-carrying capacity of concrete anchors," J. Constr. Eng. Manage., vol. 142, no. 5, pp. 04015104, 2016.

[37] T. Gupta, A. Tiwari, S. Siddique, R. K. Sharma, and S. Chaudhary, "Response assessment under dynamic loading and microstructural investigations of rubberized concrete," J. Mater. Civ. Eng., vol. 29, no. 8, pp. 04017062, 2017.

[38] Associação Brasileira de Normas Técnicas. Standard Specification for Portland Cement, C150/C150M-11, 2011.

[39] Associação Brasileira de Normas Técnicas. Standard Practice for Making and Curing Concrete Test Specimens in the Laboratory, C192/C192M-06, 2006.

[40] L. A. P. Oliveira, J. P. Castro Gomes, L. F. A. Bernardo, and M. M. M. Ramos, "Evaluation of dry mortar ratio as mixture design parameter for steel fibre reinforced self compacting concrete," Constr. Build. Mater., vol. 40, pp. 642-649, 2013.

[41] Associação Brasileira de Normas Técnicas. Molding and Curing of Concrete Cylindrical or Prismatic Test, NBR 5738, 1994.

[42] American Society for Testing and Materials. Standard Test Method for Compressive Strength of Cylindrical Concrete Specimens, C39/C39M-16b, 2016. 
[43] American Society for Testing and Materials. Standard Practice for Use of Unbonded Caps in Determination of Compressive Strength of Hardened Cylindrical Concrete Specimens, C1231-15, 2015.

[44] American Society for Testing and Materials. Standard Test Method for Rebound Number of Hardened Concrete, C805/C805M-13a, 2013.

[45] European Standard. Eurocode 2 - Design of Concrete Structures - General Rules and Rules for Buildings, EN 1992-1-1, 2004.

Author contributions: VGH conceived of the presented idea, performed the statistical analysis, wrote the manuscript with support from MACP and supervised the findings of this work. MACP designed and performed the experiments and analyzed the data. All authors discussed the results and contributed to the final manuscript.

Editors: Jose Tadeu Balbo, José Luiz Antunes de Oliveira e Sousa, Guilherme Aris Parsekian. 